\section{DIGITAL COMMONS \\ @ UNIVERSITY OF SOUTH FLORIDA}

\section{Suburban Sustainability}

Volume 3 | Issue 1

Article 4

\title{
Coupling community preferences with hydrologic evaluation of low impact development implementation in an urban watershed
}

\author{
Corinna M. Fleischmann \\ US Coast Guard Academy, corinna.m.fleischmann@uscga.edu \\ Carol Atkinson-Palombo \\ University of Connecticut, carol.atkinson-palombo@uconn.edu \\ Joseph T. Bushey \\ University of Connecticut, busheyjoseph@gmail.com \\ Eric D. Jackson \\ Connecticut Transportation Institute, University of Connecticut, erj02003@engr.uconn.edu \\ David W. Payne \\ dwpayne89@gmail.com
}

Follow this and additional works at: https://digitalcommons.usf.edu/subsust

Part of the Other Civil and Environmental Engineering Commons, and the Physical and Environmental Geography Commons

\section{Recommended Citation}

Fleischmann, Corinna M.; Atkinson-Palombo, Carol; Bushey, Joseph T.; Jackson, Eric D.; and Payne, David W. (2015) "Coupling community preferences with hydrologic evaluation of low impact development implementation in an urban watershed," Suburban Sustainability. Vol. 3 : Iss. 1 , Article 4.

http://dx.doi.org/10.5038/2164-0866.3.1.1018

Available at: https://digitalcommons.usf.edu/subsust/vol3/iss1/4

This Article is brought to you for free and open access by the Open Access Journals at Digital Commons @ University of South Florida. It has been accepted for inclusion in Suburban Sustainability by an authorized editor of Digital Commons @ University of South Florida. For more information, please contact digitalcommons@usf.edu. 


\section{INTRODUCTION}

Stormwater generation in urban areas represents an environmental challenge and is a primary focus of sustainable development (CNT, 2010; USEPA, 2007;

USEPA, 2003). Classic stormwater management aimed to rapidly deliver surface runoff from developed lands to streams, lakes and rivers (Seybert, 2006), thereby altering the hydrologic cycle in urban areas by minimizing infiltration to groundwater and enhancing runoff via impervious surfaces (Paul and Meyer, 2001; Arnold and Gibbons, 1996). The resultant hydrologic effect on urban streams has been significant increases in peak discharge, decreases in the time until the peak occurs, and lower levels of base flow in streams (Walsh et al., 2005; Paul and Meyer, 2001). Additionally, runoff from impervious surfaces and roadways delivers contaminants such as heavy metals to waterways without treatment (Watts et al., 2007). In many older urban areas (e.g., Boston, New York), the combined storm and sanitary sewer system capacity is exceeded during rain events resulting in untreated sewage discharge to nearby waterways (USEPA, 2002). Preventing rapid stormwater delivery to nearby waterways not only decreases water quantity issues but also prevents contaminant loading and is an important mechanism for restoring urban streams.

Since the late 1990's, the concept of low impact development (LID) has been emerging as a site design strategy replacing conventional methods of stormwater management. The goal of LID is to maintain or replicate the pre-development hydrologic regime by attenuating stormwater locally (Martin et al., 2007). LID aims to mimic natural ecosystem processes and fosters the use of green spaces and plants which encourages rainfall capture, improves infiltration, and reduces stormwater runoff (USEPA, 2007(b)). Various best management practices (BMPs; e.g., bioswales, bioretention basins, porous pavement, tree boxes, rain barrels) have been used in retrofitting existing development and in the planning of new development to improve the hydrologic objectives of the landscape (Lai et al., 2005; USEPA, 2000). LID site designs, also known as "green" site designs, have demonstrated hydrologic benefits (Hager, 2003; Lehner et al. 1999). Additionally, LID delivers multiple benefits beyond reducing the amount of stormwater; the ecological, economic and social benefits have made green infrastructure an increasingly popular strategy (CNT, 2010). LID can increase green space (USEPA, 2009), enhance property values (CWP, 2010) calm traffic (Matel, 2010; Li and Liu, 2009), increase community walkability, and reduce fatigue, anger, aggression and stress of automobile drivers (Barton and Pineo, 2009). Often, many of these additional objectives are addressed simultaneously, adding value to urban communities by improving community livability (Garrison and Hobbs, 2011; Roseen et al., 2011). 
As explained in more detail in the literature review, several gaps exist regarding LID performance evaluation. In this paper, we seek to address the limited evaluation of hydrologic performance at a watershed level and the lack of an evaluation of watershed-level transportation impacts. Although a need for watershed-level hydrologic assessment has been identified (Lai et al., 2005), few evaluations have been performed and no prior watershed-level studies account for potential limitations on implementation due to negative transportation impacts.

Documentation regarding transportation impacts have been limited to the benefits of traffic calming at the site-scale (Matel, 2010).

To address the gap between LID design and stormwater management decisions with respect to LID watershed scale and community, we assessed the potential benefits of LID implementation in terms of (1) stormwater runoff reduction at a neighborhood scale and (2) community preferences for each type of LID based on cost and runoff reduction. We evaluated the ability of various types and coverages of LID features on runoff reduction in a dense, urban residential neighborhood, located in Hartford, CT. Five different common LID technologies were modeled for runoff using the EPA Storm Water Management Model (SWMM), each implemented in accordance with design guidelines and accounting for the existing transportation infrastructure. We subsequently evaluated the influence of two socio-economic considerations, cost and transportation, to evaluate the impact that non-hydrologic considerations have on LID potential implementation. Traffic impacts were modeled via TransCAD and VISSIM. Our review provides an assessment of the potential for LID features to alleviate stormwater runoff at neighborhood scales under the constraints of space, cost, and traffic flow in an existing urban neighborhood.

A detailed literature review of relevant watershed-level evaluation is summarized. Following the review, we present an empirical watershed-level hydrologic evaluation. We subsequently detail an empirical cost and transportation analysis for the same watershed that was used in a household survey. A total of 139 Blue Hills' residents responded to a survey about their preferences for the five LID treatments. The survey contained photographs of each of the five LID treatments alongside information about their hydrological effectiveness and cost, and respondents were asked to rank them in order of their preferences. Additional survey questions provided information about respondent demographics, access to transportation (especially cars and on-site parking for them), general information about community problems, and experiences with flooding. Consumer preferences are then evaluated alongside the hydrologic performance to determine how these would theoretically influence the LID implementation process. 


\section{LITERATURE REVIEW}

With initial hydrologic success documented, particularly at the site-level, implementation of LID has transitioned from the pioneering phase to a phase of rapid growth. The application of specific LID designs have been optimized at the site level relative to BMP type, area, depth, and plants as well as site weather, the design precipitation amount, soil type, and percent imperviousness of the contributing area (Montalto et al. 2007; CICEET, 2007; Dreelin et al., 2006). Research efforts regarding LID optimization and implementation at the site level are abundant (e.g., Xiao, 2007; Schneider and McCuen, 2006). However, the implementation of LID and other stormwater management strategies occurs over multiple spatial scales, from site to neighborhood to watershed levels (Damodaram et al., 2010; Williams and Wise, 2006). Design factors and challenges differ for watershed-level LID implementation relative to concerns at the site level. The distribution of LID within the implementable area, local hydrology, watershed topography, and the layout and type of existing impervious area are key factors that must be considered. Additionally, factors that may be beneficial at the site scale such as traffic calming (Matel, 2010) may inhibit implementation at the neighborhood or watershed level. Neighborhood-wide traffic calming may impede emergency vehicles, commuters, and public transport, the evaluation of which has not been performed. The evaluation and decision for implementation of LID at scales beyond the site level is critical as land use management decisions are typically performed at the neighborhood or watershed scale (Arnold and Gibbons, 1996). The connection between small-scale individual LID performance and watershed-level LID implementation effectiveness is necessary to assess the potential for reduction in stormwater runoff, particularly given the inclusion of LID into recent U.S. Environmental Protection Agency (EPA) directives for stormwater and combined sewer overflow (CSO) management approaches (USEPA, 2007).

In response to the growing use of LID, the EPA has recognized the need for watershed-level assessments of LID benefits and the identification of strategic locations for BMP implementation in urban watersheds (Lai et al., 2005).

However, realistic estimates of the ability of LID to reduce stormwater in urban retrofits at the neighborhood scale are limited (Petrucci et al., 2012; Meierdiercks et al., 2010; Bedan and Clausen, 2009). Many planning evaluations at larger scales utilize site-specific information scaled up to the size of interest. Field measurements from a paired watershed study show that post construction storm flow in the LID watershed was reduced by $42 \%$ when compared to a traditional neighborhood built using typical subdivision standards (Bedan and Clausen, 2009). However, the potential reduction likely is more limited in dense, urban watersheds with increased space constraints. While Meierdiercks et al. (2010) 
demonstrated runoff reductions for a watershed with BMPs implemented, the runoff response was closer to the paired watershed without BMPs than to that of the undeveloped control. Modeling investigations predicted that $100 \%$ implementation of a mixture of BMPs would significantly reduce the runoff in Paris, France (Petrucci et al., 2012) and Kitchener, Ontario (Zimmer et al., 2007). However, neither study addressed the feasibility of implementing $100 \%$ in such a densely developed urban watershed, the costs associated with implementation, the incremental performance, nor social constrains such as transportation. More than $30 \%$ reduction in IC has been cited as an upper limit for implementation in dense, urban watersheds based on cost and space considerations (Hazen and Sawyer, 2012). And none of these prior investigations accounted for limitations on implementation due to the need to maintain traffic flow. LID has not been used extensively in urban communities primarily due to institutional and socioeconomic factors (Brown, 2009). Several studies have shown the economic factors affecting the implementation of LID (Bowman, 2012; Thurston, 2010). There are also examples in the existing peer-reviewed literature of studies focusing on community members' perceptions of LID (Keeley, 2013). However, the perceptions of homeowners about LID solutions have been rarely sought out.

\section{STUDY AREA}

A small urban watershed located in the northwest section of the City of Hartford, CT, was selected for analysis (Figure 1). The Granby watershed is a sub-section of the North Branch Park River watershed and is characterized as an urban highdensity residential neighborhood composed predominantly of privately-owned properties. The 167-ha neighborhood is contained approximately by Granby Street to the west, Blue Hills Avenue to the east, Burnham Street to the north and Westbourne Parkway to the south. Given the objective of evaluating the potential hydrologic improvement of green BMP implementation along public roadway corridors, roadway characteristics in the neighborhood will influence BMP options and performance. Total roadway distance in this area is just over $24 \mathrm{~km}$ with an average roadway width of $8.55 \mathrm{~m}$ (Supplemental Information, Table S1). The widest road, Canaan, is $11.8 \mathrm{~m}$ and the narrowest road, Holcomb, is $5.82 \mathrm{~m}$. The highest elevation is in the NE corner of the watershed and the area of study slopes gently southwest with an average slope of just over $2 \%$. 


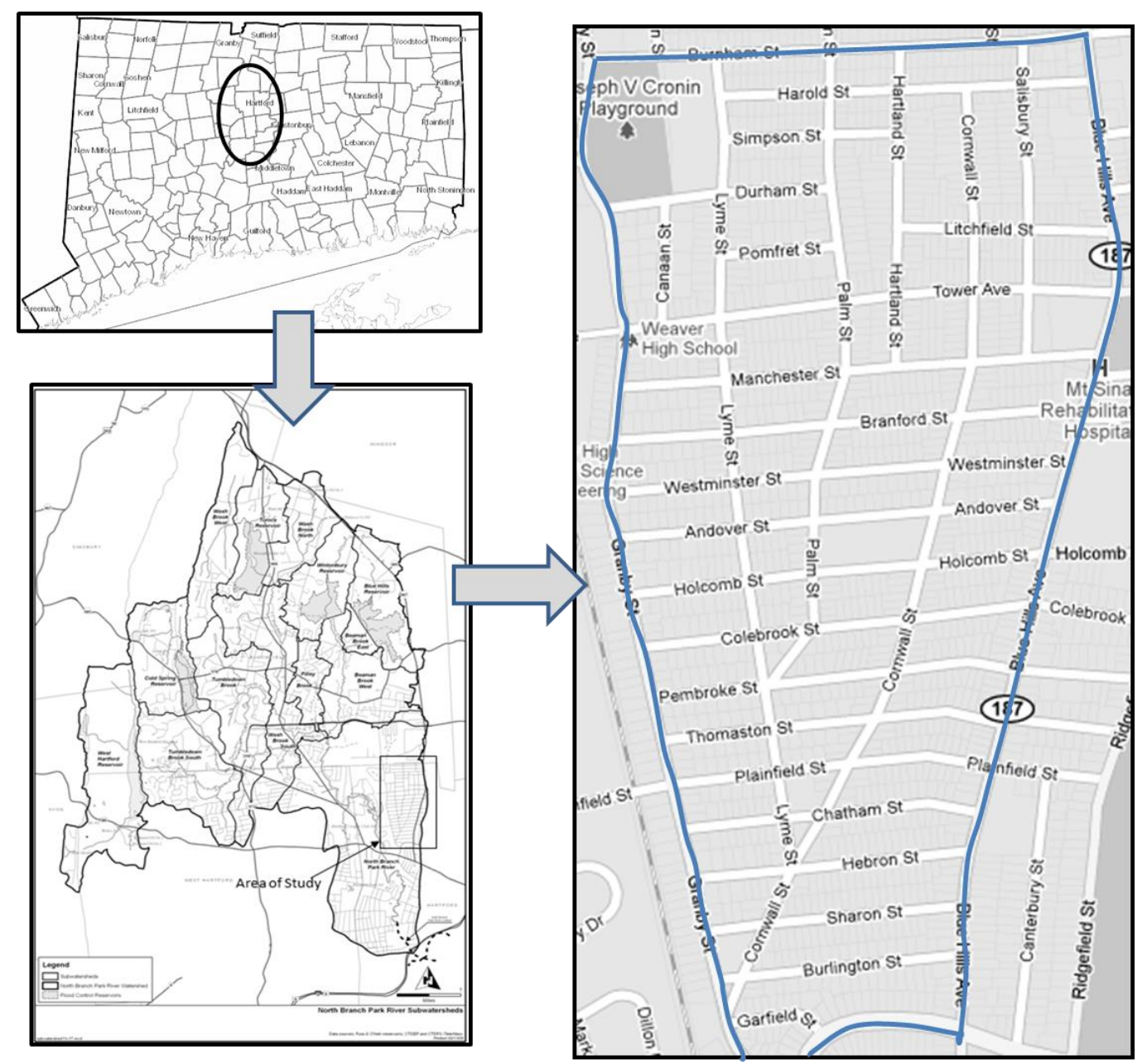

Figure 1. Location of the Granby watershed in northwest Hartford, CT, USA. The watershed represents a dense, urban watershed bordered approximately by Granby Street, Blue Hills Avenue, the city line and the Westbourne Parkway.

The design of this neighborhood typifies an urban residential design layout: the transportation infrastructure is a gridded pattern with wide, curbed streets flanked by pedestrian walkways. Little commercial development exists in the community; less than $7 \%$ by area of the watershed is town owned/commercial properties. The street pattern was designed to facilitate travel via vehicle to shopping districts located at the north and south ends of the neighborhood with the majority of residents also commuting to work outside of the neighborhood ( $\mathrm{L}$. Hunt, Blue Hills Civic Association, personal communication). In terms of the socio-economics and demographic composition, Blue Hills is effectively an ethnic enclave. Residents are predominantly African-American (95.6\%), with an average 
age of 36.4 years, and majority female $(54.5 \%)$. The median household income in Blue Hills is $\$ 51,433$, greater than that of the city as a whole $(\$ 32,820)$.

The average percent impervious cover (\% IC) for the 119 subcatchments in the Granby watershed is $45 \%$ but varies significantly by subcatchment from $0.5 \%$ to $85.6 \%$. Impervious cover is higher in the lower portion of the watershed relative to the northern part of the study area. Generally, impervious area within the watershed consists of transportation infrastructure (parking lots, driveways, roadways) and roof tops. Roof tops comprise the greatest percentage of the impervious cover within the watershed at $19 \%$ of the total land area followed by roads, driveways and parking lots with $14 \%, 10.6 \%$, and $1.4 \%$, respectively. Soils throughout all 119 catchments have been classified as moderately well-drained sandy and silty loam soils (USDA, 1986). While the base soil is suitable for infiltration and the installation of LID measures, surface soils have been heavily modified, representative of an urban environment, and may differ from the base soil regarding infiltration rate.

\section{METHODS}

We evaluated the effectiveness of LID features for minimizing watershed runoff using SWMM Version 5.0.022, a hydrologic model developed and updated by the USEPA (USEPA, 2011(b)). SWMM was selected as: (1) an existing, SWMM model of the area of interest was available (M. Heineman, CDM Smith, personal communication) and (2) Version 5.0.022 has the ability to model various LID features including bioretention basins, porous pavement, vegetative swales and rain barrels. SWMM is a dynamic rainfall-runoff watershed simulation model designed for modeling urban areas to predict the resultant runoff from each subcatchment in response to precipitation. Each subcatchment is parameterized by percent pervious/impervious, average slope, storage and infiltration. From these parameters, the model calculates a quantity of runoff relative to infiltration in response to a rain event based on the Green-Ampt Method (USEPA, 2011(b)). In addition to watershed runoff/infiltration, SWMM can incorporate engineered stormwater infrastructure (e.g., stormwater pipes, catch basins) to obtain a realistic understanding of the quantity and fate of urban stormwater. Petricci et al. (2012) provide a more detailed justification for the use of SWMM for evaluating LID at the catchment scale. The Park River sewershed SWMM model obtained from CDM also includes groundwater contributions to streams and the piping network. As LID improvements aim to enhance infiltration, the potential feedback to the engineered system via contributions from a rising groundwater table needs to be considered. Feedback from a rising groundwater due to infiltration in one subcatchment hampering infiltration in a neighboring subcatchment is an aspect unaccounted for in traditional scale-up methodology. The CDM Park River 
sewershed model was calibrated and verified for the Park River watershed, of which the Granby neighborhood is a subcatchment (Heineman et al., 2010).

To simulate LID implementation, the model subcatchment data was updated to include specific LID designs within the SWMM configuration and used to calculate resultant runoff reduction relative to the base case (no LID) for various types and coverage of LID in the watershed. With the exception of rain barrels, we focused on publicly-owned roadway right-of-ways for our assessment as alterations involving private land require owner buy-in along with an assumed increase in cost and maintenance requirements for the homeowner. Rain barrels were a specific non-roadway option included due to ease of implementation, the benefits to public awareness of stormwater concerns, and the existence of programs to promote distribution. Because most publically-owned land in this dense urban neighborhood is roadway, the potential impact of implementation and design on traffic also was considered when locating and sizing the LID features in the watershed. The impacts of LID features on the transportation network were modeled in transportation simulation models, TransCAD and VISSIM. We maintained at least one travel lane and one parking lane following LID implementation. Initial traffic pattern modeling indicated that completely closing a street would cause unnecessary congestion on alternate roadways and on-street parking in the neighborhood was maintained to satisfy residents' needs based on surveys and community meetings (data not shown). Our approach highlights a top-down watershed-level implementation evaluation. As such, we did not evaluate specific individual site feasibility, instead focusing on the overall potential for consideration of LID implementation in watershed management decisions. Regardless, regulatory requirements and sizing guidelines set forth by the Connecticut Stormwater Quality Manual (CT DEEP, 2004) for sufficient runoff removal were considered in selecting basic LID model parameters.

\section{Hydrologic Performance}

We compared the benefit of each LID feature over a range of percent coverage to assess the potential for each technology to alleviate watershed runoff. We focused on implementation in the roadway right-of-way, ignoring potential applications on private land. Therefore, the coverage was implemented based on the length of roadway in the watershed retrofitted with LID features. Roadway LID options were implemented from baseline conditions $(0 \mathrm{~km})$ in $2 \mathrm{~km}$ intervals through 12 $\mathrm{km}$ with additional model runs evaluated for $75 \%(19.3 \mathrm{~km})$ and $100 \%(24.4 \mathrm{~km})$ of the total roadway length transformed to LID to determine the maximum potential hydrological benefit of LID implementation. The streets selected for implementation were evenly distributed throughout the watershed while accounting for transportation needs and street width LID implementation limitations. Due to public transportation corridors, and the primarily north-south 
traffic flow, street selection focused on east-west secondary roadways (Table 3). As implementation coverage increased, secondary east-west streets were selected followed by secondary north-south streets. The two primary transportation corridors on either side of the neighborhood (Granby Street and Blue Hills Avenue) were not selected until the $100 \%$ implementation scenario as transportation analysis indicated that doing so would adversely affect traffic flow and negatively impact public transportation. Once specific streets were determined for implementation, the roadway length was converted to a total implementable distance in each of the 119 subcatchments for entry into SWMM by assigning the selected streets to their respective subcatchments.

LID Type. The LID features considered for analysis were divided into two categories: (1) roadway - those LID options that would be implemented in the roadway and could potentially alter traffic patterns, and (2) non-roadway - LID technologies that would not interfere with traffic. For roadway options we evaluated vegetated swales, bioretention basins and porous pavement while for non-roadway options we evaluated tree boxes and rain barrels. Given the focus on roadway LID features, implantation within the watershed was expressed as the length of roadway along which LID features were added. The length of roadway correlates to a level of IC mitigated through the design criteria outlined below for the specific LID types. Increased vegetative coverage, a comparatively easy watershed improvement, was not considered as tree coverage is already relatively dense in the current green spaces. Through analysis of aerial photographs obtained from The Metropolitan District Commission (Hartford, CT) of the watershed, approximately $75 \%$ of the available green space currently is planted with trees.

LID features were designed as stipulated in Connecticut state stormwater regulations (CT DEEP, 2004). If not specified by Connecticut, design parameters for other states were followed. All LID technologies implemented were designed in accordance with published guidelines: vegetated swales (CT DEEP, 2004), bioretention (Prince George's County, 2007) and porous pavement (ISUIT, 2009). All three LID technologies were designed to accommodate the rainfall volume of a 10-yr, 24-hr storm and the high intensity rainfall created by a 1-yr, 30-min storm as per state guidelines (CT DEEP, 2004).

For bioretention and vegetated swales, the implementable widths of the LID features were determined based on the width of the narrowest roadway considered $(7.16 \mathrm{~m})$. Two roads within the watershed are narrower, but were not used for LID implementation except in the $100 \%$ implementation analysis. With $6.1 \mathrm{~m}$ of paved roadway required for one traffic lane and one parking lane (AASHTO, 2004), the available width of roadway for LID implementation was $1.07 \mathrm{~m}$. Since this distance is insufficient, it was assumed that the grass buffer between the edge 
of the road and the sidewalk could be included when necessary affording an additional width of $1.67 \mathrm{~m}$ for a total width of $2.74 \mathrm{~m}$. The length available for implementation of roadway LID features was restricted by existing driveways. Using aerial photographs, an average distance between driveways was estimated to be $15 \mathrm{~m}$, which was used as the maximum length available for swales and bioretention cell features. The dimensions of each LID technology implemented were adjusted based on design standards (Table 1). For all roadway LID features, the remaining area of the roadway width $(6.1 \mathrm{~m})$ was assumed to be captured and treated by the LID feature.

Table 1.

Low impact development best management practices (BMPs) considered in the Granby watershed in Hartford, CT.

\begin{tabular}{|c|c|c|c|c|}
\hline & LID Type & Design Variables & Design Reference & \\
\hline \multirow[b]{2}{*}{ 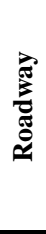 } & & Width $(m)$ & Length $(m)$ & \\
\hline & $\begin{array}{c}\text { Bioretention }^{\mathrm{a}} \\
\text { Swales }^{\mathrm{b}} \\
\text { Porous Pavement }^{\mathrm{c}}\end{array}$ & $\begin{array}{l}2.7 \\
2.44 \\
3.05\end{array}$ & $\begin{array}{c}12.2 \\
15 \\
\text { Varies by implementation distance }\end{array}$ & $\begin{array}{l}\text { CASQA, 2003; Prince } \\
\text { George's County, } 2007 \\
\text { Blick et al., } 2004 \\
\text { Legret and Colandini, 1999; } \\
\text { Houle, } 2008\end{array}$ \\
\hline \multirow{2}{*}{ 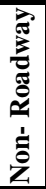 } & & Size & Spacing & \\
\hline & $\begin{array}{l}\text { Tree Boxes } \\
\text { Rain Barrels }{ }^{\mathrm{d}}\end{array}$ & $\begin{array}{c}3.34 \mathrm{~m}^{2} \\
590 \mathrm{~L}\end{array}$ & $\begin{array}{c}\text { recommended } 30.5 \mathrm{~m} \text { apart } \\
1 \text { per house in implementation area }\end{array}$ & $\begin{array}{l}\text { Virginia Department of } \\
\text { Conservation, } 1999 \\
\text { USEPA, 2011(a) }\end{array}$ \\
\hline
\end{tabular}

BMPs were separated into those impacting road right-of-way and those not implemented on roadways. LID options were implemented as a function of roadway distance of in $2 \mathrm{~km}$ increments through $50 \%$ of the watershed roadway as well as $75 \%$ and $100 \%$ of the $24.4 \mathrm{~km}$ of roadways in the watershed.

${ }^{\text {a }}$ Area per feature $=33.4 \mathrm{~m} 2$. Recommended sizing of $4.6 \mathrm{~m}$ by $12.2 \mathrm{~m}$ cannot be attained given watershed restrictions. Implemented bioretention does meet all mandated design criteria.

${ }^{\mathrm{b}}$ Area per feature $=37.2 \mathrm{~m} 2$. A width of $2.44 \mathrm{~m}$ was selected based on the recommended minimum design slope of 3 .

${ }^{\mathrm{c}}$ The implemented width is the width of a parking lane, $3.05 \mathrm{~m}$. Length is the total length of roadway selected.

${ }^{\mathrm{d}}$ An average roof area was estimated to be $158 \mathrm{~m}^{2}$ based on aerial photographs. It was assumed that each barrel drains half the roof.

The implementation of the two non-roadway LID technologies was designed to correspond to the implementation distances used for the roadway LID technology. Tree box implementation for each subcatchment was determined using the specific street lengths used for roadway LID and the criterion identified (Table 1). For rain barrels, a ratio of rooftops per roadway length was applied to the street length per catchment to determine the total number of rain barrels to implement within each of the 119 catchments. The ratio of rooftops per distance was determined using an average value estimated visually for the number of rooftops per street for five of the streets within the watershed and applied to the 
remainder of the watershed. In this watershed, the average roof area per house was $158 \mathrm{~m}^{2}$ which resulted in approximately $6.1 \mathrm{~m}^{2}$ of roof area per meter of roadway. We assumed one rain barrel per house with that rain barrel draining half of the roof. This method of calculating rain barrel coverage allowed for an estimated value of the amount of impervious surface that each 590-L rain barrel was able to treat. The number of houses with a rain barrel increased with each successive model run matching the increase in distance of implementable roadway.

The calculated design area for each LID feature was entered into the appropriate subcatchment in SWMM and evaluated for each runoff reduction scenario. The total runoff for the watershed was computed by summing the runoff from each model subcatchment. Results of each run subsequently were compared to the base conditions for the watershed (i.e. no LID implementation or $0 \mathrm{~km}$ of roadway length) to determine a percent runoff reduction. Only the runoff from the appropriate impervious surface (roadway, roof) was assumed to be treated by the LID options that were implemented, ignoring potential runoff contributions to the LID feature from nearby grass areas. While subjected to increased runoff in urban areas due to compaction, grass area is likely to still have higher infiltration rates relative to roof and pavement areas. Simulations were performed using a 1-yr storm event, the minimum design storm for most LID technologies (ISUIT, 2009). Precipitation data collected at Bradley International Airport in Windsor Locks, CT from 1954 to 2009 were used to select a historical 1-yr storm for this assessment. The airport is located approximately $13.7 \mathrm{~km}$ north of the study area. We selected a historical 1-yr storm event (April 10, 1983) that produced $6.3 \mathrm{~cm}$ of rainfall over a $15-\mathrm{hr}$ period resulting in an intensity of $0.419 \mathrm{~cm} / \mathrm{hr}$ and was verified to be a 1-yr event using local IDF curves (Miller et al., 2002).

Modeling LID in SWMM. In SWMM, five modeling process layers are available to model LID controls: the surface layer, the pavement layer, the soil layer, the storage layer and the underdrain layer. The surface layer corresponds to the ground surface that receives direct rainfall and run-on from up-gradient land areas, stores excess inflow in depression storage and generates surface outflow that, in this case, flows onto down-gradient land areas. The pavement layer provides specifics about the characteristics of the particular pavement mix and is used solely when modeling porous pavement. The soil layer is the engineered soil mixture used in bioretention cells to support vegetative growth. The storage layer is a bed of crushed rock or gravel that provides hydrologic storage in the LID feature. The underdrain system conveys water out of the storage layer into a common outlet pipe or chamber. All of the LID controls modeled in SWMM provide some amount of rainfall/runoff storage and evaporation of stored water with the exception of rain barrels (USEPA, 2011(b)). 
The variables and criteria for each layer of each LID technology were selected based on recommendations from the literature or the CT Stormwater Manual (CT DEEP, 2004; Table 2). For uniformity among the LID technologies, no underdrain was assumed for tree boxes. The goal of this study was to determine the surface runoff reduction in the watershed. We did not include an underdrain, a common element of tree box design, because we wanted to ensure any excess water would exit the tree box design as runoff rather than directly entering the storm sewer system via the tree box underdrain.

Table 2.

SWMM LID design criteria for porous pavement (PP), vegetative swales (Swale), bioretention basins (Bio), rain barrels (RB), and tree boxes (TB).

\begin{tabular}{|c|c|c|c|c|c|c|}
\hline & Process Layer & $\mathbf{P P}$ & Swale & Bio & RB & TB \\
\hline \multirow{5}{*}{ 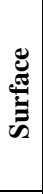 } & Storage depth $(\mathrm{cm})$ & $0^{1}$ & $30.5^{2,3}$ & $7.6^{2}$ & NA & $30.5^{4}$ \\
\hline & Vegetation Volume Fraction & 0 & 0.1 & 0.15 & NA & 0.15 \\
\hline & Surface Roughness & 0.03 & 0.25 & 0.075 & NA & 0.075 \\
\hline & Surface slope (\%) & 1 & 1 & 0 & NA & 0 \\
\hline & Swale side slope & NA & $3^{2}$ & NA & NA & NA \\
\hline \multirow{5}{*}{$\begin{array}{l}\vec{\Xi} \\
\vec{\Xi} \\
\vec{\Xi} \\
\vec{\Xi}\end{array}$} & Thickness $(\mathrm{cm})$ & $15.25^{5}$ & NA & NA & NA & NA \\
\hline & Void Ratio (-) & $0.175^{5}$ & NA & NA & NA & NA \\
\hline & Impervious Surface Fraction & 0 & NA & NA & NA & NA \\
\hline & Permeability $(\mathrm{cm} / \mathrm{hr})$ & $864^{5}$ & NA & NA & NA & NA \\
\hline & Clogging Factor & 0 & NA & NA & NA & NA \\
\hline \multirow{4}{*}{ 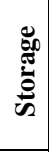 } & Heigth (cm) & 30.5 & NA & 30.5 & 130 & 30.5 \\
\hline & Void Ratio (-) & 0.75 & NA & 0.75 & NA & 0.75 \\
\hline & Conductivity (cm/hr) & 25.4 & NA & 25.4 & NA & 25.4 \\
\hline & Clogging Factor & 0 & NA & 0 & NA & 0 \\
\hline \multirow{4}{*}{ 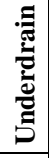 } & Drain coefficient $(\mathrm{cm} / \mathrm{hr})$ & 0 & NA & 0 & 0 & 0 \\
\hline & Drain exponent & 0.5 & NA & 0.5 & 0.5 & 0.5 \\
\hline & Drain offset height $(\mathrm{cm})$ & 0 & NA & 0 & 0 & 0 \\
\hline & Drain delay (hrs) & NA & NA & NA & 6 & NA \\
\hline \multirow{7}{*}{$\overline{\overline{\mathscr{n}}}$} & Thickness (cm) & NA & NA & $122^{2}$ & NA & $61^{6}$ \\
\hline & Porosity (vol fraction) & NA & NA & 0.5 & NA & 0.5 \\
\hline & Field Capacity (vol fraction) & NA & NA & 0.2 & NA & 0.2 \\
\hline & Wilting Point (vol fraction) & NA & NA & 0.08 & NA & 0.1 \\
\hline & Conductivity (cm/hr) & NA & NA & 1.27 & NA & 1.27 \\
\hline & Conductivity slope & NA & NA & 10 & NA & 10 \\
\hline & Suction head $(\mathrm{cm})$ & NA & NA & $8.9^{6}$ & NA & $8.9^{6}$ \\
\hline
\end{tabular}

Vegetation volume fraction is the storage depth filled by vegetation. Very dense growth value of 0.2 . Surface roughness given by Manning's $n$ (Rough concrete - 0.03; short grass pasture, no brush - 0.25; flood plains, heavy brush - 0.075). Surface slope of LID feature assumed to be 0 for Bio/TB and 1 for PP/Swale. Slope should not exceed 2.5\%. Assume entire implementable area pervious for PP. Drain coefficient is zero if no underdrain. NA - not applicable.

${ }^{1}$ ISUIT, 2009

${ }^{2}$ CASQA, 2003

${ }^{3}$ Blick et al., 2004

${ }^{4}$ Portland SW Manual, 2005

${ }^{5}$ PCA, 2004

${ }^{6}$ Prince George's Country, 2007 


\section{Community Preferences}

Cost. From a practical management standpoint, the implementation cost also affects the selection of a suitable BMP. Costs per unit area of construction were estimated from published values (Table 4) and applied to each LID feature and coverage. Generalized implementation costs were used for the cost estimates selected from within the range of published estimates for the roadway LID options (Table 4). Costs will vary with site conditions, being highly dependent on location and availability of materials, specific design, local labor and material rates, real estate values, and contingencies (USEPA, 2011(a)), Dreyer, 2012; USEPA, 2011; CICEET, 2007; LIDC, 2005; RRDP, 2001; USEPA, 2000). Values were selected from the upper end of the cost range for the current study due to the high degree of urbanization in the watershed which would require the disruption of the existing impervious cover.

For the two non-roadway options considered, regional cost estimates were utilized. Tree boxes were assumed to cost $\$ 2,500$ per unit, the actual implementation cost of tree boxes at the UNH Stormwater Center (\$US 2007; CICEET, 2007). For rain barrels, 156 gal barrels were chosen for this assessment due to their commercial availability. The assumed cost of installation for each rain barrel is $\$ 195$ per barrel based on reported average cost of $\$ 1.25$ per gallon published by the USEPA (USEPA, 2011(a)).

Cost is a key aspect in assessing the practicality of LID implementation. A more thorough examination of the factors affecting the variability of costs and the potential impact that those costs have on influencing LID selection would be beneficial and are detailed elsewhere. Given the focus on a top-down watershed approach, specifically hydrology, a more detailed cost evaluation was beyond the current scope. For this analysis, we present a simplified cost estimate to place the hydrologic benefits in context. A more detailed investigation of the variability in costs requires additional knowledge about the cost distribution functions, without which a uniform distribution would be assumed presenting a trivial assessment. Therefore, while interesting, a more thorough evaluation of the cost uncertainty is beyond the scope of this study.

Transportation Impact. The traditional four-step planning model (Trip Generation, Trip Distribution, Mode choice and Assignment) was used to simulate traffic on the network in TransCAD and VISSIM. Census tract data were used to estimate the number of trips generated from and attracted to each zone within the network producing an origin-destination (O-D) matrix. This matrix was assumed to be static and not impacted by LID improvements. Also for simplicity, the mode choice was assumed to be negligible and not impacted by LID improvements. The resulting O-D Matrix was then assigned to routes throughout 
the network to get travelers from their origin to their destination. These assignments were made based on the current characteristic of each link of the network. As the proposed LID improvements were applied stepwise to the network, the assigned O-D matrix was updated to reflect the new characteristics of each link. For example, if the $2.4 \mathrm{~km}$ of roadway were to be converted to a oneway street with a grassy swale, the links would be changed to one way travel links, thus restricting simulated traffic to use this link only for one way traffic. The resulting change in traffic flow and patterns were noted for proposed LID scenario and level of implementation. Overall changes in vehicle miles traveled (VMT), vehicle hours traveled (VHT) and number of vehicles traveling on each link (flow) were summarized to characterize the watershed-wide traffic impact of the specified LID implementation.

\section{Survey of Residents' Experiences with Flooding and Preferences for LID.} Residents of the Blue Hills neighborhood were surveyed about their experiences with flooding, and their preferences for adopting LID as a solution. A total of 139 compete surveys were obtained. The survey contained photographs of the five low-impact development (LID) treatments described above and hydrologic information regarding the effectiveness of each option as a solution to storm water flooding. Respondents were asked to rank each of these options from 1 (most desirable) to 5 (least desirable). They were also asked to prioritize community improvement options by distributing a total of 10 points between four items: increasing green space, maintaining on-street parking, reducing traffic, and avoiding increasing travel time. Another section contained a list of community problems including unsupervised teenagers, flooding, and traffic, and asked respondents if they thought that each represented a big problem, small problem, Data were also collected about respondents' demographics, homeownership, automobile ownership and access, and availability of parking.

\section{RESULTS}

\section{Hydrologic Performance}

A comparison of percent runoff reduction to implementation distance along the roadway right-of-way was conducted using SWMM for each LID technology (Figure 2a). Porous pavement, bioretention and vegetated swales were comparable in terms of runoff reduction per implementable distance. All of the roadway LID technologies assessed ranged from $1.6 \%$ percent reduction at the 2 $\mathrm{km}$ implementation distance through $33 \%$ reduction for full implementation ( $100 \%$ or $24.4 \mathrm{~km}$ of roadway implementation; Figure $2 \mathrm{a}$ ). The trends were approximately linear with variation in hydrologic response with increased 
coverage due to street-specific differences (Table 3). Certain streets, and therefore catchments, have a greater potential to reduce runoff with the implementation of a BMP due to their existing \% IC and width. Rain barrels and tree box filters were less effective methods, with maximum runoff reduction potential with $100 \%$ implementation of $4 \%$ and $6 \%$, respectively (Figure 2a). Rain barrels account for a very small decrease in percent reduction due to the relatively small amount of runoff treated. Tree box filters were not as effective in capturing runoff due to their small size $\left(3.34 \mathrm{~m}^{2}\right)$ and the large amount of space suggested between the boxes $(30.5 \mathrm{~m})$ in order to maximize performance (Virginia Department of Conservation, 1999). Decreasing the space between the boxes would increase tree box effectiveness proportionally. Based on the comparison of percent runoff reduction with implementable distance, porous pavement, vegetated swales and bioretention cells would be appropriate options for maximizing runoff reduction in this type of urban watershed.
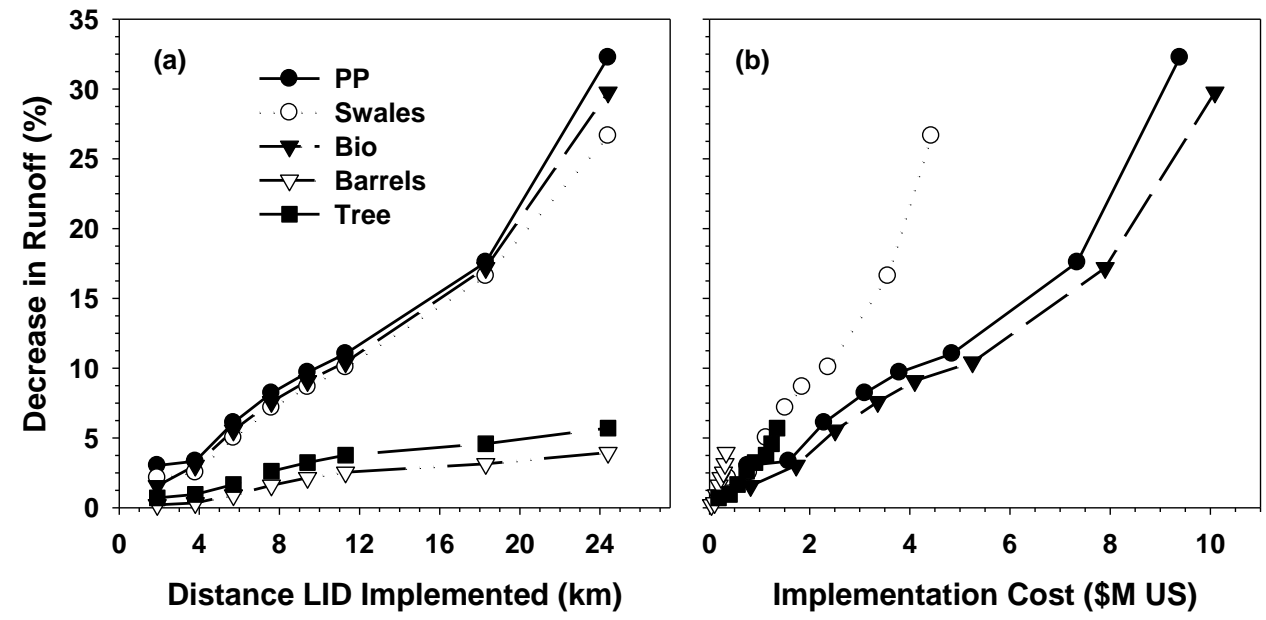

Figure 2. Comparison of percent runoff reduction to implementation distance (a) and cost (b) of low impact development best management practice (BMP). BMPs were implemented as a function of linear roadway distance over $2 \mathrm{~km}$ intervals through $12 \mathrm{~km}$ and then $75 \%$ and $100 \%$ of the available roadway. BMPs included roadway (swale, bioretention and porous pavement) and nonroadway (tree boxes and rain barrels) options. Runoff was estimated using a SWMM model constructed and validated for the area for the Metropolitan District Commission. Costs were estimated from averages of published average costs as given in Table 4. 
Table 3. Street implementation lengths for LID evaluation.

\begin{tabular}{|c|c|c|c|c|c|c|}
\hline & \multicolumn{6}{|c|}{ Total Coverage Within Watershed (km) } \\
\hline Street & 2 & 4 & 6 & 8 & 10 & 12 \\
\hline Garfield & 0.18 & & 0.18 & 0.18 & 0.18 & 0.18 \\
\hline Burlington & & 0.48 & 0.48 & 0.48 & 0.48 & 0.48 \\
\hline Sharon & & 0.50 & 0.50 & 0.50 & 0.50 & 0.50 \\
\hline Hebron & & 0.52 & 0.52 & 0.52 & 0.52 & 0.52 \\
\hline Chatham & & 0.57 & 0.57 & 0.57 & 0.57 & 0.57 \\
\hline Plainfield & & & 0.60 & 0.60 & 0.60 & 0.60 \\
\hline Thomaston & & & 0.64 & 0.64 & 0.64 & 0.64 \\
\hline Pembroke & & & & 0.69 & 0.69 & 0.69 \\
\hline Colebrook & & & & 0.78 & 0.78 & 0.78 \\
\hline Andover & 0.84 & & & & 0.84 & 0.84 \\
\hline Westminster & & & & & & 0.88 \\
\hline Branford & & & & & & 0.90 \\
\hline Manchester & & & & & & 0.92 \\
\hline Tower & & & & & 0.94 & 0.94 \\
\hline Canaan & & & & & & \\
\hline Pomfret & & & & 0.19 & 0.19 & 0.19 \\
\hline Litchfield & & & & 0.41 & 0.41 & 0.41 \\
\hline Durham & & & 0.42 & 0.42 & 0.42 & 0.42 \\
\hline Simpson & & 0.32 & 0.32 & 0.32 & 0.32 & 0.32 \\
\hline Harold & & 0.71 & 0.71 & 0.71 & 0.71 & 0.71 \\
\hline Burnham & 0.93 & 0.93 & 0.93 & 0.93 & 0.93 & 0.93 \\
\hline Lyme & & & & & & \\
\hline Palm & & & & & & \\
\hline Hartland & & & & & & \\
\hline Cornwall & & & & & & \\
\hline Salisbury & & & & & & \\
\hline Holcomb & & & & & & \\
\hline Granby & & & & & & \\
\hline Westbourne & & & & & & \\
\hline Blue Hills & & & & & & \\
\hline
\end{tabular}

Length given for each street (in $\mathrm{km}$ ) under a given coverage scenario.

\section{Community Preferences}

Cost. Runoff reduction potential was then evaluated against implementation cost to assess the cost-effectiveness of each LID technology for a given implementation distance along the roadways (Figure 2b). LID options differ in the cost per implementation length (i.e., area; Table 4). Adjusting the runoff reduction performance to account for implementation cost demonstrated that swales were the most cost effective BMP for the study area. Vegetated swales yielded the highest percent of runoff reduction for the lowest cost for the implementation size, largely due to the lower construction costs $\left(\$ 82.45 / \mathrm{m}^{2}\right)$. Construction costs for PP and bioretention cells render these technologies more expensive options. While non-transportation options afforded minimal runoff reduction, the lower costs, particularly for rain barrels, may increase the feasibility of implementation on a larger scale. 
Table 4. Cost estimates for low impact best management practices (BMPs) evaluated.

\begin{tabular}{|c|c|c|c|c|}
\hline LID Technology & Cost ID & Cost & Unit & Reference \\
\hline Porous Pavement (PP) & $\begin{array}{c}\text { Implemented } \\
\text { Low } \\
\text { High }\end{array}$ & $\begin{array}{c}\$ 128.09 \\
\$ 5.38 \\
\$ 124.86\end{array}$ & $\begin{array}{l}\text { per } m^{2} \\
\text { per } m^{2} \\
\text { per } m^{2}\end{array}$ & $\begin{array}{c}\text { Dreyer, } 2012 \\
\text { LIDC, } 2005 \\
\text { USEPA, 2011a }\end{array}$ \\
\hline Swale & $\begin{array}{c}\text { Implemented } \\
\text { Low } \\
\text { High }\end{array}$ & $\begin{array}{l}\$ 82.45 \\
\$ 3.23 \\
\$ 82.00 \\
\end{array}$ & $\begin{array}{c}\text { per } \mathrm{m}^{2} \\
\text { per } m^{2} \\
\text { perm length }\end{array}$ & $\begin{array}{c}\text { USEPA, } 2011 \\
\text { RRDP, } 2001 \\
\text { USEPA, } 2000\end{array}$ \\
\hline Bioretention & $\begin{array}{c}\text { Implemented } \\
\text { Low } \\
\text { High }\end{array}$ & $\begin{array}{l}\$ 161.46 \\
\$ 32.29 \\
\$ 430.56\end{array}$ & $\begin{array}{l}\text { per } \mathrm{m}^{2} \\
\text { per } m^{2} \\
\text { per } m^{2}\end{array}$ & $\begin{array}{c}\text { USEPA, } 2011 \\
\text { USEPA, } 2000 \\
\text { LIDC, } 2005\end{array}$ \\
\hline Rain Barrel & Implemented & $\$ 195.00$ & per barrel & USEPA, 2011a \\
\hline Tree Box & Implemented & $\$ 2,500.00$ & per box & CICEET, 2007 \\
\hline
\end{tabular}

Average costs were estimated from published values in the literature.

Transportation. Transportation impacts increased with $5.7 \mathrm{~km}$ of LID implementation (Figure 3). VMT, VHT and Flow increased between 3.8 and 5.7 $\mathrm{km}$ of implementation, indicating that vehicles traveling through the neighborhood will have to travel further to complete the same trip (VMT) and require additional time to travel a similar distance (VHT). Flow, a measure of the number of vehicles that travel along a road, summed over all links, indicates that vehicles are now required to take less direct route to get from their origin to their destination. With LID implementation, the number of turns vehicles perform, the roads vehicles travel, and time required to travel from origin to destination increase. These metrics are relatively constant through $3.8 \mathrm{~km}$ of implementation before increasing significantly by approximately $4 \%$ between 3.8 and $5.7 \mathrm{~km}$ of implementation. Above $5.7 \mathrm{~km}$ of implementation, the metrics again remain relatively constant through $12 \mathrm{~km}(50 \%)$ of implementation. From this data, researchers calculated that $64.7 \%$ of respondents own their own homes and $29.5 \%$ of respondents rent their residence. Few respondents depended upon the availability of on-street parking, as $92.8 \%$ had a private driveway at their place of residence. The average household size in Blue Hills is 3.03 (Census 2010). More than half $(53.2 \%)$ of respondents' households include children under the age of 18. 


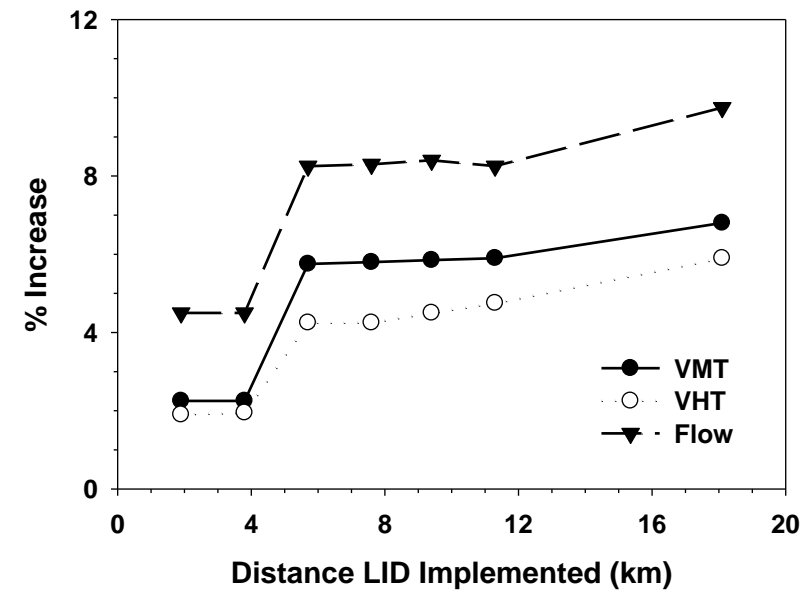

Figure 3. Impact of roadway low impact development BMP implementation on transportation metrics, vehicle miles traveled (VMT), vehicle hours traveled (VHT) and flow. Percent increase evaluated using VISSIM and TransCAD relative to the existing base case. Lines do not reflect trends.

\section{Survey of Residents' Experiences with Flooding and Preferences for LID.}

The majority of households surveyed (58.6\%) had between 2 and 4 people, and over half $(53.2 \%)$ of all households had at least one child. The vast majority of households $(91.3 \%)$ had access to at least one car. Over one-third (36.2\%) of households had a single vehicle, while an additional $42.8 \%$ of households had two cars. Over two-thirds $(64.7 \%)$ of respondents own their own homes. Few respondents depended upon the availability of on-street parking, as $92.8 \%$ had a private driveway at their place of residence. The average household size in Blue Hills is 3.03 (Census 2010). More than half (53.2\%) of respondents' households include children under the age of 18 . In response to the questions about community problems, more respondents $(24.5 \%)$ found traffic to be a "big problem" in their community than any other community issue. Respondents also found unsupervised teenagers $(15.8 \%)$ and flooding $(13.7 \%)$ to be a "big problem" in the community. With respect to increasing greenspace, $14.4 \%$ of persons did not find increasing green space in their communities to be important (0 points), $43.8 \%$ found it to be somewhat important (1-3 points), 30.9\% found it to be important (4-6 points), and 10.8\% found it to be very important (7-10 points). With respect to maintaining on-street parking, $22.3 \%$ did not find it important (0 points), $57.6 \%$ found it somewhat important (1-3 points), 19.4\% found it to be important (4-5 points), and $0.7 \%$ found it to be very important ( 9 points). With respect to reducing traffic, $12.2 \%$ did not find it important (0 
points), $54 \%$ found it somewhat important (1-3 points), $28 \%$ found it to be important (4-6 points), and 5.7\% found it to be very important (7-10 points). With respect to avoiding increasing travel time, $36 \%$ did not find it important (0 points), $56.9 \%$ found it somewhat important (1-3 points), $7.2 \%$ found it to be important (4-6 points), while no respondents found avoiding an increase in travel time to be very important (7-10 points). With respect to preferences for LID, the following results were obtained. For swales, $14.4 \%$ of respondents ranked it as their \#1 preference, $21.6 \%$ of respondents ranked it as their \#2 preference, and $40.3 \%$ of respondents ranked it as one of their bottom two preferences. For porous pavement, $37.4 \%$ ranked it as their \#1 preference, $15.1 \%$ ranked it as their \#2 preference, and $32.4 \%$ ranked it as one of their bottom 2 choices. For tree boxes, $9.4 \%$ ranked it as their \#1 preference, $22.3 \%$ ranked it as their \#2 preference, and $43.8 \%$ ranked it as one of their bottom 2 choices. For rain barrels, $20.9 \%$ ranked it as their \#1 preference, $12.9 \%$ ranked it as their \#2 preference, and $50.3 \%$ ranked it as one of their bottom 2 choices.

\section{DISCUSSION}

Full implementation of a single LID stormwater BMP resulted in a maximum stormwater runoff reduction of $32 \%$. In the dense, urban setting evaluated here, the $\% \mathrm{IC}$ was high which resulted in a significant amount of stormwater runoff $(15.8 \mathrm{~cm})$ generated by a $1-y r$ storm event. Our predictions of LID performance are lower relative to prior studies of complete LID implementation, which cite up to $97 \%$ capture (Petrucci et al., 2012; Zimmer et al., 2007). The higher runoff reductions in prior studies for complete coverage result from implementation of a combination of LID types in all available spaces in the watershed. Our results reflect single LID features implemented only in the transportation right-of-way (TROW). Combinations of porous pavement and either swales or bioretention may be possible in the TROW representing a potential capture of nearly $41 \%$, still lower than prior studies. Additional minor runoff reductions of $9.6 \%$ could be achieved through simultaneous implementation of the two non-TROW options, tree boxes and rain barrels along with those in the TROW. In all, the total runoff reduction achieved (51\%) would still be lower relative to prior studies as we limited the consideration of implementation on private land. Although the complete coverage investigated in prior studies is technically feasible, actual implementation would likely be limited by space, cost, and social preference (e.g., non-willingness to forego parking). Implementation in a dense urban setting has been suggested to be limited to 30\% (Hazen and Sawyer, 2012).

Our results demonstrate that transportation requirements will likely limit the ability to implement LID features on roadways, even on secondary arterials. 
While hydrologic benefits continue to increase with implementation, so do negative transportation impacts. Given the significant increase in transportation metrics above $3.8 \mathrm{~km}$ of implementation (Figure 3), stormwater mitigation using roadway LID features is limited in such developed watersheds. Runoff reduction from such implementation would be capped at $2 \%$, significantly less than that with full coverage. The increases in transportation metrics could result from the additional total LID coverage or the selection of specific streets. The low traffic volumes and lack of proximity for the incremental roadways selected for the $6 \mathrm{~km}$ implementation suggest that roadway selection would not have an impact. However, specific street selection was not explicitly investigated. Regardless, local watershed managers need to consider transportation constraints when developing stormwater management plans involving LID.

In the Granby watershed, transportation considerations limit potential implementation of the cost-optimal LID approach to approximately $16 \%$ of the road length, a significant reduction from the $24.4 \mathrm{~km}$ representing complete implementation. The runoff reduction resulting from the realistic implementation of just one LID technology along $4 \mathrm{~km}$ of TROW is minimal. To improve performance, watershed managers could consider implementing a mix of options. In addition to $4-\mathrm{km}$ of vegetated swales (5.0\% runoff reduction), PP can be utilized in a different 4-km section of the watershed. With a possible combined runoff reduction of $8 \%$ (Figure 2a), swales and PP in concert could provide runoff reduction not possible with the implementation of a single LID technology. Including rain barrels in a combined 4-km scenario at half of the homes in the watershed in addition to the swales and the PP, increases the potential runoff reduction to $11 \%$ (Figure $2 \mathrm{a}$ ). Implementing multiple types of BMPs to achieve watershed goals is encouraged (USEPA, 2004; USEPA, 2001) and could come closer to achieving pre-development hydrologic conditions (Damodaran et al., 2010; Petrucci et al., 2012; Zimmer et al., 2007).

Cost of implementation could inhibit the use of specific BMPs (e.g., PP) and multiple BMPs. Augmenting the watershed implementation plan to incorporate multiple LID technologies (e.g., swales, PP, and rain barrels) would increase the reduction in IC and decrease the runoff; however, the increase in the cost of implementation may be a challenge. Similarly, PP implementation at levels $>4$ $\mathrm{km}$ may be possible, either for parking or travel lanes. PP would not alter traffic flow nor reduce parking, but represents a more expensive option (Table 3).

Our runoff results demonstrate the incremental hydrologic benefit of LID implementation at a watershed scale and the importance of socio-economic considerations (Figure 2). Many social factors can influence the decision-making process. We have chosen to examine transportation as a representative example to demonstrate the need to include such non-hydrologic considerations in decisionmaking. Given the limited benefit per LID feature and the cost of implementation, 
many management plans are implemented based on opportunities as options become available given space and cost constraints (USEPA, 2010). While each LID option is evaluated prior to implementation, an evaluation of the overall hydrologic benefit and potential transportation impacts at the watershed level are lacking. The benefits of large-scale implementation across watersheds has been documented via hydrologic models (Petrucci et al., 2012; Zimmer et al., 2007). As noted by Petrucci et al. (2012), watershed level assessments are a necessity for evaluating policy and planning prior to implementation; yet, many such plans lack the necessary hydrologic evaluation at the catchment level to support decisions on placement. Our study builds on prior watershed-level evaluations (Petrucci et al., 2012; Zimmer et al., 2007) by demonstrating the incremental hydrologic benefits achievable per LID implementation (Figure 2). Additionally, watershed managers need to consider the total amount of implementation allowable given the constraints (including cost and transportation) of the existing built environment during the decision-making process to best assess the optimal location and type of BMP to employ. Our results suggest that transportation will be a limitation on implementation along TROWs and that managers target wider streets for implementation where larger swale size could be implemented without negatively impacting transportation (Figure S1).

While the two non-roadway options do not offer the runoff reduction potential that the roadway options offer, they are worth considering for other reasons. Tree boxes provide the benefit of greenery on an urban sidewalk and could be maintained by the municipality rather than relying on a homeowner for maintenance and up keep. Tree boxes have similar runoff reduction to rain barrels, but may be limited by the higher cost. While offering the smallest runoff reduction, rains barrels represent a very affordable option (Figure 2b). Rain barrels also provide the visual reminder of efforts toward sustainability and stormwater reduction that have proven positive in changing the mindset of a community; individual community members can get involved with minimal financial investment which contributes to generating public support for further LID improvements (USEPA, 2010). Since neither of the non-roadway options impacts transportation, each can be implemented without impacting transportation to increase runoff reduction. However, these features present the challenge of involving private owners in implementation and maintenance.

Although over half of the respondents $(56.8 \%)$ experienced some problem with flooding, only $13.7 \%$ of all respondents indicated that it was a "big problem", less than traffic (24.5\%) and unsupervised teens $(15.8 \%)$. Despite the fact that many people indicated that increasing greenspace was either important or very important, there was strong opposition to swales and tree boxes, with $40.3 \%$ and $43.8 \%$ of respondents ranking these two options in their bottom two preferences. With $52.5 \%$ of those surveyed ranking porous pavement as one of 
their top two preferences, porous pavement received the strongest community support. The least popular option was rain barrels, with $50.2 \%$ of respondents ranking them in their bottom 2 choices. A number of respondents mentioned some problems associated with trees such as: tree roots being the cause of flooding problems, trees causing downed power lines, and tree boxes near the commercial area being planted but not maintained. Some of these factors may contribute to the strong opposition to tree boxes. Separately, some respondents expressed frustration with the amount of time that it has taken the authorities to address the flooding issues and with the quality of the work that was being done (specifically with respect to leaving potholes in the road after undertaking repairs). This suggests that there may be a lack of trust that any structures that are built will be maintained, which could result in the relatively strong opposition to swales that would need to be kept clear of debris.

\section{CONCLUSIONS}

Model results indicated that the most cost effective LID technology in this developed watershed is swales. Relative to prior investigations, the percentage of stormwater reduction using LID was limited in this dense urban setting due to the constraints of predevelopment, with a maximum decrease of $32 \%$ for $100 \%$ implementation of a single LID technology in the TROW. However, transportation requirements and the limitations of implementing pervious solutions on private land limited the amount of potential mitigation from a single LID technology to $16 \%$ of the roadway length in the watershed. Utilizing multiple technologies outside of the TROW, such as rain barrels and tree boxes, provides a mechanism to increase runoff mitigation within the constraint of maintaining traffic flow. PP may also be implemented along the area not treated by swales without negatively impacting traffic metrics, albeit at a higher cost.

When evaluating management decisions, an LID implementation strategy should be employed from a watershed-level perspective for the prediction of stormwater runoff reduction. Additionally, non-hydrologic factors including cost, transportation requirements, and community preferences will affect LID selection and will likely limit full-scale watershed implementation. As the preferences of communities throughout the country will vary based on economics, access to public transportation, and the severity, frequency and variety of hydrologic issues experienced, each community will respond differently and support or contest the implementation of LID in their community. While further site-specific assessment would be necessary should LID be deemed a stormwater runoff reduction strategy, an overall evaluation of the potential reduction that includes socioeconomic considerations of the target community is necessary to determine the role of LID in the overall watershed plan. Assessing the incremental hydrologic 
benefit of LID features simultaneously with cost and non-hydrologic requirements provides a measure of the implementability of LID in a catchment. 


\section{ACKNOWLEDGMENTS}

We thank M. Heinemann from Camp, Dresser and McKee, Inc. for guidance and assistance with SWMM, the MDC for approval to use the model, and the Connecticut Center for Transportation and Livable Systems for financial support. We also acknowledge assistance with initial model simulations from University of Connecticut undergraduate students B. Soloway and M. Welch and United States Coast Guard Academy undergraduate students A. Murray, E. Maher, L. Delgado, K. Coleman, J. Bobo, and D. Shockey. 


\section{REFERENCES}

American Association of State Highway and Transportation Officials (AASHTO), 2004. A policy on Geometric Design of Highways and Streets. Washington, DC. Arnold, C.L. and Gibbons, C.J., 1996. Impervious Surface Coverage: The Emergence of a Key Environmental Indicator. Journal of the American Planning Association, 62(2),243-259.

Barton, S. and Pineo, R., 2009. Human Benefits of Green Space. University of Delaware College of Agriculture and Natural Resource, January.

Bedan, E.S. and Clausen, J.C., 2009. Stormwater Runoff Quality and Quantity from Traditional and Low Impact Development Watersheds. Journal of the American Water Resources Association, 45(4):998-1008.

Blick, S.A., Kelly, F., and Skupien, J.J., 2004. New Jersey Stormwater Best Management Practices Technical Manual. New Jersey Department of Environmental Protection, Division of Watershed Management. April. California Stormwater Quality Association (CASQA), 2003. California Stormwater Best Management Practices Handbook - New Development and Redevelopment. www.cabmphandbooks.com.

Center for Neighborhood Technology (CNT), 2010. The value of Green Infrastructure: A Guide to Recognizing Its Economic, Environmental and Social Benefits. American Rivers.

Connecticut Department of Energy and Environmental Protection (CT DEEP). 2004. Connecticut Stormwater Quality Manual.

Cooperative Institute for Coastal \& Estuarine Environmental Technology (CICEET), 2007. University of New Hampshire Stormwater Center Annual Report. UNH/NOAA.

Center for Watershed Protection (CWP), 2010. New York State Stormwater

Management Design Manual. New York State Department of Environmental Conservation.

Damodaram, C., Giacomoni, M.H., Khedun, C. P., Holmes, H., Ryan, A., Saour, W., and Zechman, E. M., 2010. Simulation of Combined Best Management

Practices and Low Impact Development for Sustainable Stormwater Management. Journal of the American Water Resources Association, 46(5), 907-18.

Dreelin, E.A., Fowler, L., and Carroll, C.R., 2006. A test of porous pavement effectiveness on clay soils during natural storm events. Water Resources, 40,799805.

Dreyer, B.T., 2012. Leading by Example: Low Impact Development and Sustainable Infrastructure in Municipal Communities. Presented at the NEWEA Stormwater Seminar, May 2, 2012. Hartford, CT: New England Water Environment Association (NEWEA). 
Garrison, N. and Hobbs, K., 2011. Rooftops to Rivers II: Green strategies for controlling stormwater and combined sewer overflows. Natural Resources Defense Council Hager, M.C., 2003. Lot-level approaches to stormwater management are gaining ground. Journal of Surface Water Quality Professionals. January/February. Hazen and Sawyer, 2012. Green Infrastructure Feasibility Scan for Bridgeport and New Haven, CT. Evaluation of Green Technologies to Manage Wet Weather Flows. Report. Apirl.

Heineman, M., X. Huang, A. Prasad, S. Craig, S. Dent and C. Banciulescu, 2010. Integrated Collection Systems Model for Hartford, Connecticut. In: World Environment and Water Resources Congress 2010: Challenges of Change. American Society of Civil Engineers, Conference Proceedings, Providence, RI, pp.3314-3328.

Houle, K.M., 2008. Winter performance assessment of permeable pavements: a comparative study of porous ashpalt, pervious concerete and conventional asphalt in a norther climate. MSCE Thesis. Univeristy of New Hampshire.

Iowa State University Institute for Transportation (ISUIT), 2009. Iowa

Stormwater Management Manual.

http://www.intrans.iastate.edu/pubs/stormwater/index.cfm

Lai, F., Shoemaker, L. and Riverson, J., 2005. Framework Design for BMP

Placement in Urban Watersheds. Proceedings of the 2005 World Water and

Environmental Resources Congress. May 15-19, 2005, Anchorage, Alaska: EWRI 2005: Impacts of Global Climate Change.

Legret, M. and Colandini, V., 1999. Effects of a Porous Pavement with Reservoir Structure on Runoff Water: Water Quality and Fate of Heavy Metals. Water Science and Technology, 39(2), 111-117.

Lehner, P., Aponte Clark, G. P., Cameron, D. M. and Frank, A. G., 1999. Stormwater Strategies: Community Responses to Runoff Pollution. National Resources Defense Council, June.

Li, C. and Liu, C., 2009. Study on the Green Traffic Planning System of New

Rural Communities. Proceedings of the Ninth International Conference of Chinese Transportation Professionals: Critical Issues in Transportation Systems Planning, Development and Management. August 5-9, 2009, Harbin, China: ICCTP 2009. 1175-1180.

Li, H., Sharkey, L.J., Hunt, W.F. and Davis, A.P., 2009. Mitigation of Impervious Surface Hydrology Using Bioretention in North Carolina and Maryland. Journal of Hydrologic Engineering, 14(4), 407-415.

Low Impact Development Center (LIDC), 2005. Fairfax County, Virginia. Low Impact Development, Best Management Practice (BMP) Factsheet. www.lowimpactdevelopment.org/fairfax.htm 
Matel, L.J., 2010. An Urban Approach to LID. Civil Engineering, September, 6469.

Miller, D.R., Warner, G.S., Ogden, F.L. and DeGaetano, A.T., 2002. Precipitation in Connecticut. Connecticut Institute of Water Resources.University of Connecticut, Storrs.

Montalto, F., Behr, C., Alfredo, K., Wolf, M., Arye, M., and Walsh, M., 2007. Rapid assessment of the cost-effectiveness of low impact development for CSO control. Landscape Urban Plan, 82, 117-131.

Paul, M.J. and Meyer, J.L., 2001. Streams in the Urban Landscape. Annual Rev. Ecol. Syst. 32, 333-65.

Portland Concrete Association (PCA), 2004. Pervious Concrete Mixtures and Properties, Concrete Technology Today CT043, 25(3), 3-4.

Prince George's County, Maryland, 2007. Bioretention Manual. Department of Environmental Resources Programs and Planning Division. Prince George's County, MD.

http://www.princegeorgescountymd.gov/Government/AgencyIndex/DER/ESG/Bio retention/pdf/Bioretention\%20Manual_2009\%20Version.pdf.

Roseen, R., Janeski, T., Houle, J., Simpson, M. and J. Gunderson, 2011. Forging the Link: Linking the Economic Benefits of Low Impact Development and Community Decisions. University of New Hampshire Stormwater Center, the Virginia Commonwealth University and Antioch University New England. July.

Rouge River National Wet Weather Demonstration Project (RRDP), 2001.

Planning and Cost Estimating Criteria for Best Management Practices. TRNPS25.00. Rouge Program Office. Wayne County, Michigan

Schneider, L.E., and McCuen, R.H. 2006. Assessing the Hydrologic Performance of Best Management Practices. Journal of Hydrologic Engineering, 11(3), 278281.

Seybert, T., 2006. Stormwater Management for Land Development: Methods and Calculations for Quantity Control. New York:Wiley \& Sons, Inc.

United States Department of Agriculture (USDA), 1986. Urban Hydrology For

Small Watersheds. Natural Resources Conservation Service, Conservation

Engineering Division. Technical Release 55 (WINTR-55)

USEPA, 1999, Storm Water Technology Fact Sheet: Vegetated Swales, 832-F-99006. Washington, DC: Office of Water.

USEPA, 2000. Low Impact Development (LID); A Literature Review, EPA-841-

B-00-005. Washington, DC: Office of Water and Low Impact Development

Center.

USEPA, 2001.National Menu of Best Management Practices for Stormwater Phase II, http://cfpub.epa.gov/npdes/stormwater/menuofbmps/index.cfm. Washington, DC. 
USEPA, 2002. Wastewater Management, Controlling and Abating Combined Sewer Overflows. 2001-P-00012. Washington, DC: Office of Inspector General Evaluation.

USEPA, 2003. Protecting Water Quality from Urban Runoff, EPA 841-F-03-003. Washington, DC: Nonpoint Source Control Branch.

USEPA, 2004. The Use of Best Management Practices (BMPs) in Urban Watersheds, EPA/600/R-04/184.Washington, DC: Office of Research and Development.

USEPA, 2007. Reducing Stormwater Costs through Low Impact Development (LID) Strategies and Practices, EPA 841-F-07-006. Washington, DC: Nonpoint Source Control Branch.

USEPA, 2009. Incorporating Low Impact Development into Municipal

Stormwater Programs, EPA 901-F-09-005. EPA New England, Region 1.

USEPA, 2010. Green Infrastructure Case Studies: Municipal Policies for

Managing Stormwater with Green Infrastructure, EPA 841-F-10-004.

Washington, DC: Office of Wetlands, Oceans and Watersheds.

USEPA, 2011(a). Green Long-Term Control Plan-EZ Template: A Planning Tool for Combined Sewer Overflow Control in Small Communities, EPA-833-R-09-

001. Washington, DC: Office of Water.

USEPA, 2011(b). Office of Risk Management Water Research. Storm Water Management Model (SWMM), version 5.0.022 with Low Impact Development (LID) Controls [software]. Available from

http://www.epa.gov/nrmrl/wswrd/wq/models/swmm/

Virginia Department of Conservation, 1999. Virginia Stormwater Management Handbook. First Edition.

Walsh, C.J., Roy, A.H., Feminella, J.W., Cottingham, P.D., Groffman, P.M. and Morgan, R.P., 2005. The urban stream syndrome: current knowledge and the search for a cure. Journal of the North American Benthological Society,24, 706723.

Watts, R.D., Compton, R.W., McCammon, J.H., Rich, C.L., Wright, S.M., Owens, T. and Ouren, D.S., 2007. Roadless space of the conterminous United States. Science, 316, 736-738.

Williams, E.S. and Wise, W.R., 2006. Hydrologic Impacts of Alternative Approaches to Storm Water Management and Land Development. Journal of the American Water Resources Association, 42, 443-455.

Xiao, Q., McPherson, E.G., Simpson, J.R., and Ustin, S.L., 2007. Hydrologic processes at the urban residential scale. Hydrological Processes, 21, 2174-2188. 